\title{
Integrating Traditional and Scientific Knowledge through Collaborative Natural Science Field Research: Identifying Elements for Success

\author{
HENRY P. HUNTINGTON, ${ }^{1}$ SHARI GEARHEARD,${ }^{2}$ ANDREW R. MAHONEY ${ }^{3}$ and ANNE K. SALOMON ${ }^{4}$
}

\author{
(Received 23 December 2010; accepted in revised form 21 April 2011)
}

\begin{abstract}
We discuss two recent projects to examine the role of collaborative environmental fieldwork both in research and in the interactions between academically trained researchers and experienced local residents. The Bidarki Project studied black leather chitons (Katharina tunicata) in the lower Kenai Peninsula, Alaska. Its conclusion that chiton declines are part of a serial decline of intertidal invertebrates drew on collaborative fieldwork, archaeological data, historical records, and interviews with local residents. The Siku-Inuit-Hila Project studied sea ice in Barrow, Alaska; Clyde River, Nunavut; and Qaanaaq, Greenland. Quantitative data from locally maintained observation sites were supplemented by knowledge exchanges among hunters from the communities and by discussion in local working groups to develop an understanding of the physical dynamics and human uses of sea ice at each locale. We conclude that careful planning and preparation, along with the effort to build strong personal relationships, can increase the likelihood that collaborative fieldwork will be productive, enjoyable, and rewarding.
\end{abstract}

Key words: traditional knowledge, fieldwork, collaborative fieldwork, ecology, black leather chiton, Katharina tunicata, sea ice, collaboration, Alutiiq, Inuit

RÉSUMÉ. Nous discutons de deux récents projets ayant eu pour but d'examiner le rôle d'études environnementales collaboratives sur le terrain, tant sur le plan de la recherche que sur le plan des interactions entre les chercheurs universitaires et les résidents expérimentés des localités visées. Le projet Bidarki se penchait sur les chitons noirs (Katharina tunicata) de la basse péninsule Kenai, en Alaska. La conclusion selon laquelle le déclin des chitons fait partie d'un déclin en série d'invertébrés intertidaux s'appuie sur des études collaboratives sur le terrain, sur des données archéologiques, sur des dossiers historiques ainsi que sur des entrevues de résidents des localités. Pour sa part, le projet Siku-Inuit-Hila a eu comme objectif d'étudier la glace de mer à Barrow, en Alaska; à Clyde River, au Nunavut; et à Qaanaaq, au Groenland. Les données quantitatives provenant de lieux d'observation entretenus localement ont été supplémentées par les échanges de connaissances des chasseurs des collectivités et par les discussions de groupes de travail locaux visant à mieux comprendre la dynamique physique et l'utilisation humaine de la glace de mer à chaque endroit. Nous en concluons que des travaux de planification et de préparation attentionnés, accompagnés d'efforts visant à nouer des liens personnels étroits, peuvent accroitre la possibilité que les études collaboratives sur le terrain soient productives, agréables et valorisantes.

Mots clés : connaissances traditionnelles, étude sur le terrain, étude collaborative sur le terrain, écologie, chiton noir, Katharina tunicata, glace de mer, collaboration, Alutiiq, Inuit

Traduit pour la revue Arctic par Nicole Giguère.

\section{INTRODUCTION}

In recent decades, the use of traditional knowledge in ecological research has grown considerably (e.g., Johannes, 1981; Berkes, 1999; Ford and Martinez, 2000). Much attention has been given to the similarities and differences between traditional and scientific knowledge (e.g., Agrawal, 1995; Ingold and Kurttila, 2000; Pierotti and Wildcat, 2000; Cruikshank, 2001), as well as to the various ways in which traditional and scientific knowledge can or cannot be used together (e.g., Huntington et al., 1999, 2004a, b; Nadasdy, 1999; Huntington, 2000; Dowsley and Wenzel, 2008). However, relatively few papers (e.g., Huntington et al., 2002; Parrado-Rosselli, 2007; Brook et al., 2009) have discussed the key elements and techniques that help to establish productive connections between different knowledge systems and between knowledge holders associated with those systems.

\footnotetext{
${ }^{1}$ Corresponding author: Pew Environment Group, 23834 The Clearing Drive, Eagle River, Alaska 99577, USA;

hhuntington@pewtrusts.org

${ }^{2}$ National Snow and Ice Data Center, University of Colorado at Boulder, PO Box 241, Clyde River, Nunavut X0A 0E0, Canada; shari.gearheard@nsidc.org

${ }^{3}$ Geophysical Institute, University of Alaska Fairbanks, PO Box 757320, Fairbanks, Alaska 99775, USA; mahoney@gi.alaska.edu

${ }^{4}$ School of Resource and Environmental Management, Simon Fraser University, 8888 University Drive, Burnaby, British Columbia V5A 1S6, Canada; anne.salomon@sfu.ca

(C) The Arctic Institute of North America
} 


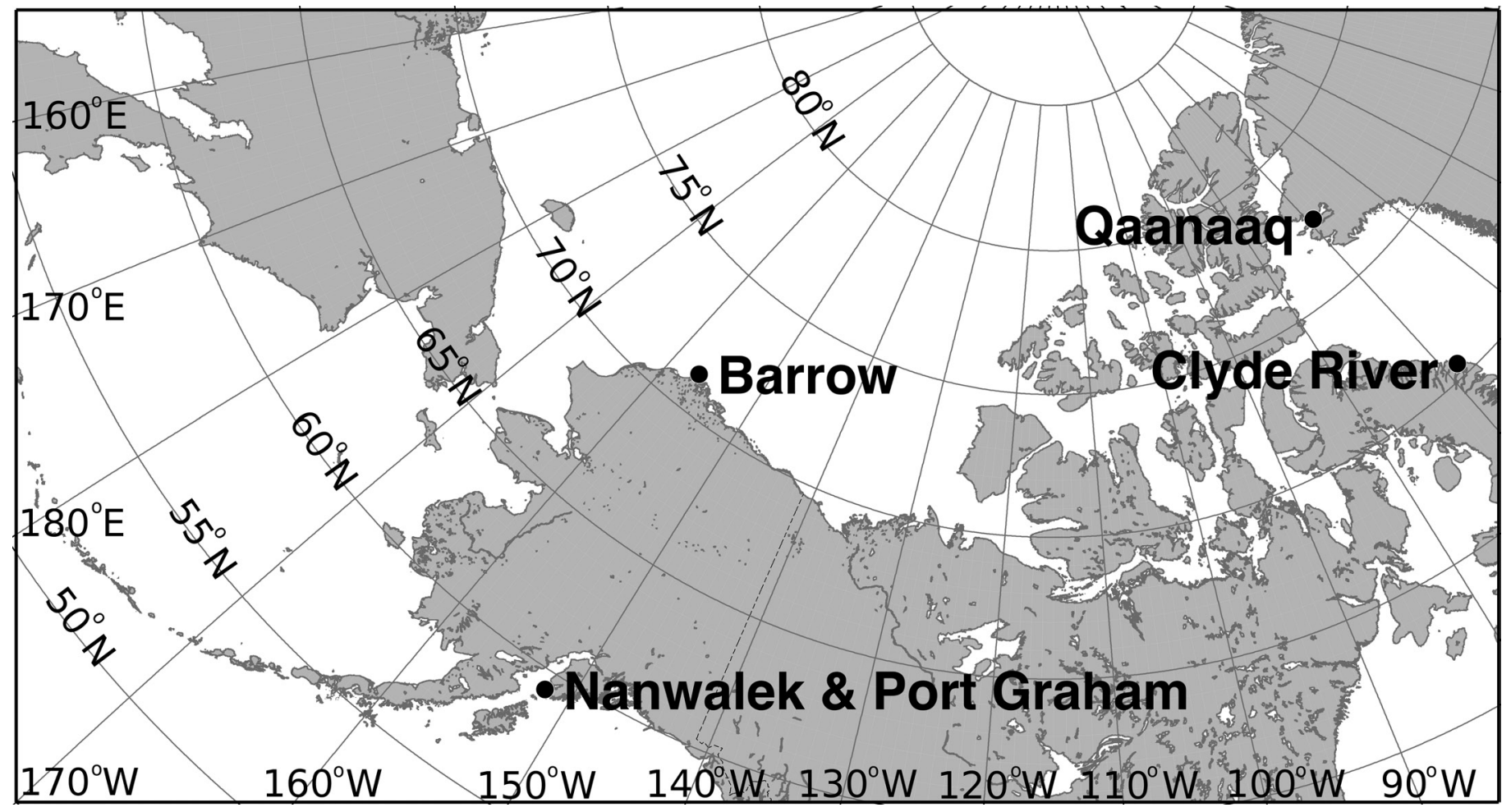

FIG. 1. Locations of the studies. The Bidarki Project took place in Nanwalek and Port Graham, Alaska. The Siku-Inuit-Hila Project took place in Barrow, Alaska; Clyde River, Nunavut, Canada; and Qaanaaq, Greenland.

Most approaches to working with traditional knowledge (also known as indigenous knowledge and by various other terms) draw on methods from the social sciences, such as interviews (e.g., Briggs, 1986; Huntington, 1998), workshops (e.g., Huntington et al., 2002), participant observation (e.g., Malinowski, 1922; Jorgensen, 1989; Bernard, 1995), and mapping exercises (Naidoo and Hill, 2006; Murray et al., 2008). Fundamental to these approaches is the recognition that working with holders of traditional knowledge is a social process, requiring both interpersonal relationships and awareness of cultural differences (e.g., Ferguson and Messier, 1997; Huntington et al., 2006; Gearheard and Shirley, 2007). Participatory research in its various forms provides further insight and experience in this regard (e.g., Smucker et al., 2007) and has included efforts to document and apply traditional knowledge in conservation and sustainability (e.g., Areki and Fiu, 2005; Fraser et al., 2006; Berkes et al., 2007). "Citizen science," in contrast, involves the engagement of large numbers of individuals who help collect data, but generally have little or no involvement in study design or interpretation of data (e.g., Parris, 1999; Schnoor, 2007).

Involving holders of traditional knowledge in natural science field research has received less attention in terms of methodology, perhaps because it draws less obviously on established social science methods. Yet the role of local residents in such fieldwork at various stages, from research design to field research to data analysis and reporting, has the potential for social interactions and situations that foster needed trust, mutual understanding, and novel ecological insights (e.g., Parrado-Rosselli, 2007). Ecologists and other natural scientists often have local field guides and assistants, and thus the opportunity to explore the applicability of traditional knowledge to their research through collaborative fieldwork, but they may not be aware of either the possibility of doing this or the ways in which it can be done. This paper is thus written primarily for such an audience rather than for experienced practitioners of social science techniques.

We review two recent projects in which we have participated in order to identify tangible outcomes of collaborative fieldwork, as well as those approaches that appear to help realize the potential benefits of such cooperation, from the point of view of the academically trained scientists involved. (An examination of collaborative fieldwork from the point of view of local residents would also be worthwhile, but is beyond the scope of this paper.) Those benefits included (a) the use of knowledge concerning local distribution and abundance of species or environmental conditions that can help make fieldwork successful and safe, (b) the opportunity to discuss ecological knowledge in situ, (c) the creation of a common basis of experience for subsequent discussion and analysis, and (d) a strong foundation on which future collaborations for research and conservation can be built.

\section{THE BIDARKI PROJECT}

The Bidarki Project, which took place on the lower Kenai Peninsula in south-central Alaska from 2002 to 2006, was 
TABLE 1. Four key observations made by local Alutiiq residents that informed our understanding of the ultimate causes of bidarki declines.

\begin{tabular}{|c|c|c|}
\hline Period & Observation & Quote(s) \\
\hline $1800 s-1960$ & Change in the spatial distribution of subsistence harvest effort & $\begin{array}{l}\text { [Before the Russian occupation] when resources became low, people } \\
\text { moved on. Then they would go back when resources returned. They always } \\
\text { traveled, from fall to spring. That's what is happening here: we're not } \\
\text { moving. }\end{array}$ \\
\hline
\end{tabular}

1930s-1960 Greater abundance of shellfish before the sea otter recovery

1960s-2000s Serial decline of shellfish
We used to be able to get all the Dungeness we wanted. We used to collect clams and cockles; nobody ever missed a tide. We were so rich because there was so much out there. 1960s-2000s Increased pressure on Katharina from changes in predation by humans and sea otters
[Sea otters] came back in the early 60s. The population exploded in the late $70 \mathrm{~s}$, early $80 \mathrm{~s}$.

The urchins were the first to go - then crab, then the clams. Bidarkis, they're the most recent change.
Years ago, people didn't only go for bidarkis. Everything was availablewhy would they want to just hit the bidarkis? They had crab, mussels, and urchins. The sea otter will change their diet, like any other animal, like us. They turn to bidarkis. Because now that's our only diet from here. designed to investigate the relative roles of natural factors and shoreline harvest activities in leading to recent declines of the black leather chiton (Katharina tunicata) (Salomon et al., 2007). The lead researcher (A. Salomon), an ecologist, established several research sites near the villages of Port Graham and Nanwalek, Alaska (Fig. 1). Design of the research questions, selection of the survey sites, and the actual fieldwork were carried out during successive visits in collaboration with local Alutiiq residents, who harvest the chitons (known locally as "bidarkis") and were concerned about their decline. For more details about the collaborative process on this project, see Salomon et al. (2011).

The bidarki is an ecologically important grazer known to drive intertidal productivity and biodiversity (Paine, 1992, 2002; Markel and DeWreede, 1998). A. Salomon sought to examine the relative effects of various factors that influence the current spatial variation in bidarki density and size structure. These include consumer-driven factors, such as predation by sea otters (Enhydra lutris), shorebirds, or sea stars and shoreline collection by humans; resourcedriven factors, such as productivity of kelp; and physical factors, such as wave exposure and water temperature. On the basis of distance from the communities and accessibility, residents of Nanwalek and Port Graham identified 11 study sites that captured a gradient of shoreline collection effort. The study included a variety of field ecology techniques (quantitative surveys and experimental manipulations), and local members of the research team carried out several duties, from counting and measuring bidarkis, to monitoring potential predators, setting up experimental bidarki exclosures, tagging kelp to measure growth rates, and measuring wave exposure.

Working together in the field allowed the research team members to imagine and discuss what heavily and lightly harvested shores might have looked like in the past, both prior to contact with Europeans and in the post-contact period after the fur trade had extirpated the sea otter, a major consumer of nearshore shellfish. The field effort provided a common basis of experience in the local environment, a chance for A. Salomon and local researchers to develop common referents, so that discussions could begin with phrases like "As we saw the other day at... ." These discussions set the stage for more formal interviews and group discussions, including spatially explicit harvest surveys, semi-directive interviews (Huntington, 1998), and community presentations. Importantly, the traditional knowledge interviews pointed the way to another analytical element, examining invertebrates' remains collected from a 700-yearold shell midden. This prehistoric perspective broadened and enriched the research team's understanding of changes in subsistence shoreline collection practices. Overall, the traditional knowledge effort resulted in four critical observations made by local residents (Table 1, Fig. 2A).

Quantitative field data from the Bidarki Project revealed that current spatial variation in bidarki density and biomass is driven by both human exploitation (Fig. 2B) and sea otter predation, the relative intensity of predation from the two predators varying among sites. That contemporary finding was combined with the observations of serial declines of invertebrates (Fig. 2A, B), coincident changes in human behavior (including the change from a semi-nomadic pattern to increasingly permanent settlements, improved extractive technologies such as outboard motors, a regional crash in commercial crustacean fisheries, and the erosion of culturally based season and size restrictions), and the reestablishment of sea otters. This more complete picture of the history and social-ecological context of recent field results allowed the researchers to propose that a spatial concentration of shoreline collection effort through time, the serial depletion of alternative marine invertebrate prey, and 


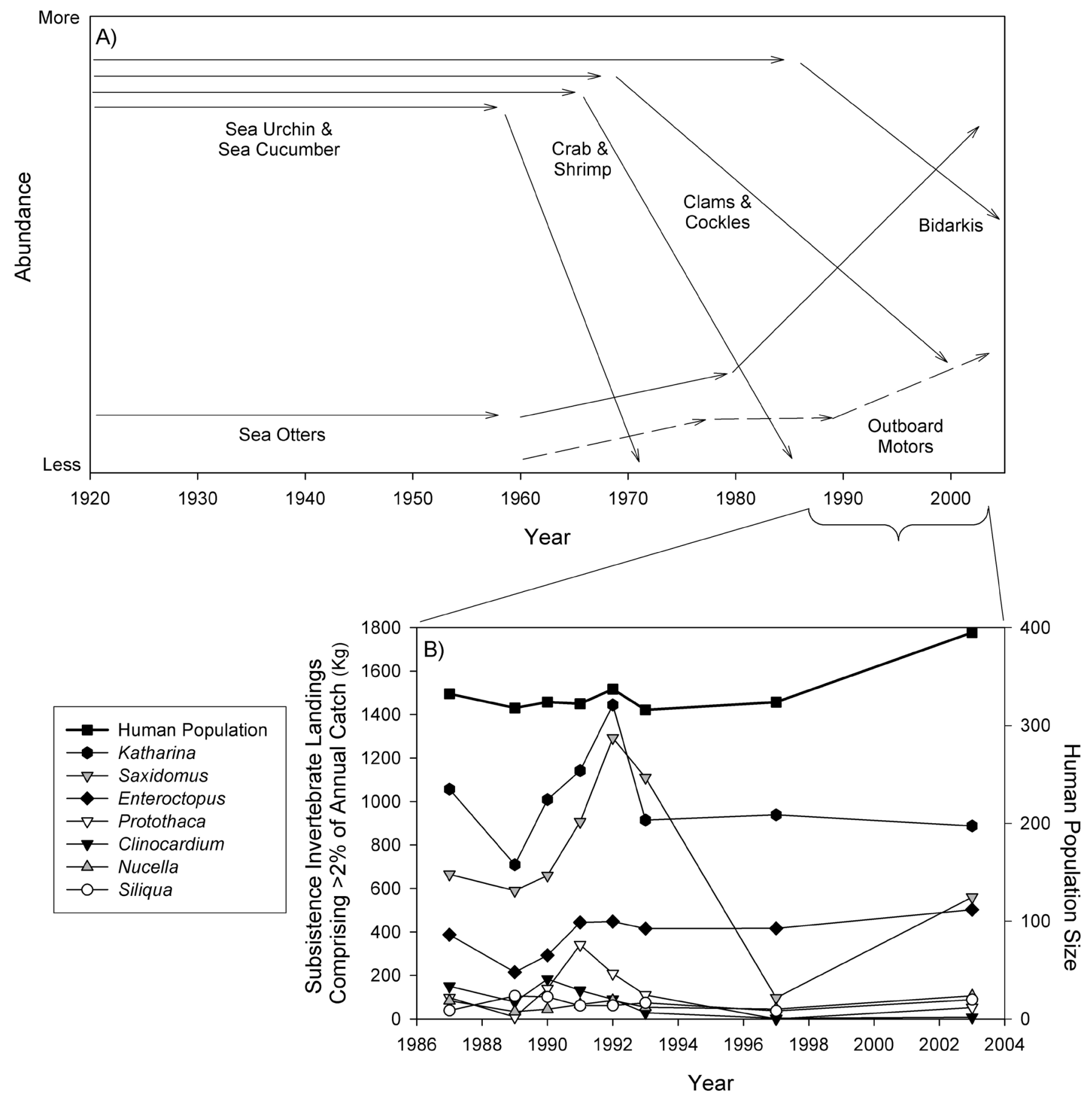

FIG. 2. (A) Serial depletion of marine invertebrates in relation to other factors from 1920 to 2003 revealed through qualitative traditional knowledge (Salomon et al., 2007). (B) Subsistence landings of each species that constituted more than $2 \%$ of the annual invertebrate catch from Nanwalek and Port Graham, Alaska, from 1987 to 2003, and local human population size. (Redrawn from Salomon et al., 2007.)

prey switching by both human and sea otter predators have likely led to intensified predator impacts on bidarkis — and thus, to their recent localized decline.

By itself, an analysis of the contemporary factors driving the variation in bidarkis in space could not have explained the ultimate causes governing localized declines in bidarkis through time. By sharing observations and ideas triggered by ecological patterns and by their common experiences in the field, scientists and traditional knowledge holders collectively devised alternative hypotheses regarding bidarki declines, ruling some out and narrowing in on others.

Beyond the formal field components of the Bidarki Project, other activities established A. Salomon's willingness to listen, learn, and give back to the community. These activities included learning how to drive a skiff through rough seas and local navigational hazards, co-organizing annual community meetings that featured art and stories in 


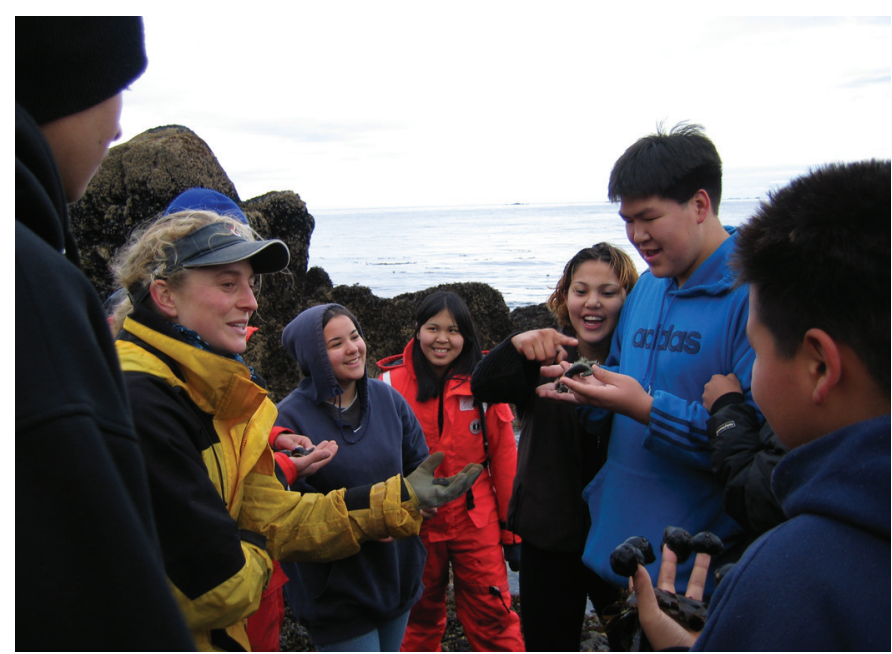

FIG. 3. Anne Salomon and students from Port Graham exchange their knowledge of intertidal food webs in the field. Seastars, like the one held by Josh Anahonak (student holding the mottled star, Evasterias troschelii) are predators that consume small bidarkis (Katharina tunicata). Photo courtesy of Anne Salomon.

addition to science updates, and planning school programs that encouraged local students to talk with elders and learn words for major food web components in Sugcestun (the local language), along with scientific concepts (Fig. 3).

\section{THE SIKU-INUIT-HILA PROJECT}

The Siku-Inuit-Hila ("Sea Ice-People-Weather") Project was a comparative study of sea ice and its use by humans in Barrow, Alaska; Clyde River, Nunavut; and Qaanaaq, Greenland (Fig. 1), conducted from 2007 to 2009 (See Huntington et al., 2010, which also has more information about the collaborative process on this project). The project grew out of a previous study in Barrow and Clyde River (Gearheard et al., 2006), which in turn drew on existing research relationships established by $\mathrm{H}$. Huntington in Barrow and S. Gearheard in Clyde River. The study had three main components, designed and executed by a collaborative team of Inuit and scientists. First, an ongoing sea-ice monitoring program was established in each community, creating a modest community-based network to observe the thickness, growth, and melting of sea ice (Mahoney and Gearheard, 2008; Mahoney et al., 2009). Second, the team of hunters, elders, and academic researchers traveled to each of the other communities for observations and discussion about sea-ice patterns, dynamics, local use, and recent changes (Gearheard et al., 2006). Third, each community created a working group of sea-ice experts, which met monthly over three sea-ice seasons to discuss current sea-ice conditions; document terminology; create maps related to sea-ice features, dynamics, and use; and complete other activities and discussions on topics they identified as important to an understanding of sea ice. On the basis of traditional knowledge, the sites for monitoring stations were selected to represent local environmental variability in relation to local sea-ice practices and travel routes, while also occupying stable sea ice to minimize the risks to people, equipment, and data posed by potential ice movements. After some basic training from S. Gearheard and A. Mahoney, local researchers began weekly observations at each of the monitoring stations in their areas, sending their data to A. Mahoney for archiving and analysis.

Collaborative research was built into the project from the beginning, especially in the design of the community-based sea-ice observing network. First, the instrumentation was designed to be easy to install, operate, and maintain while collecting robust data (Mahoney and Gearheard, 2008). Second, local experts selected safe measurement sites to be representative of sea ice typically used by the community. At Qaanaaq, for example, it is well known among local residents that under-ice currents erode the sea ice from beneath in spring. In order to examine this phenomenon, local experts from that community recommended that monitoring stations form a transect from the shore to the center of Inglefield Fjord across a gradient in current strength. The results from the first season of ice observations at Qaanaaq demonstrated that the sea ice was indeed thinnest in the center of the fjord, the ice growth was retarded by heat input from the ocean, and thinning from the bottom contributed substantially to the spring melt (Mahoney et al., 2009).

This result helped reveal a key difference between the local sea-ice environment at Qaanaaq and those at Clyde River and Barrow, where monitoring data indicated that surface melt made a greater contribution to the overall thinning of the sea ice in the summer. Figure 4 shows data from the first two seasons (2006-07 and 2007-08) on the growth and melt of ice in each community. The data reveal interannual variability in sea-ice thickness and snow depth at each community; in addition, spring melt had a different pattern in each location. They also demonstrate the scientific value of establishing and maintaining observatories of this kind.

During the community exchange visits, all team members (hunters, elders, and scientists) traveled together on the sea ice by snowmobile or dog team (Fig. 5), and their travels included multi-day trips to visit other communities or distant hunting camps. Studying sea ice in situ was key to the research, as the sea ice was the common denominator for all team members: thus each person could contribute to the fieldwork from his or her own perspective despite differences in background, experience, and home community. The field trips themselves established a common experience across the research team, which grew with subsequent site visits and, critically, allowed all members to discuss the same set of observations according to their own fields of expertise without having to take independently acquired data at face value. This experience was especially important in terms of understanding the use of sea ice; the team learned through doing, not just through talking.

The local expert working groups provided an extended opportunity for residents to record their knowledge about 


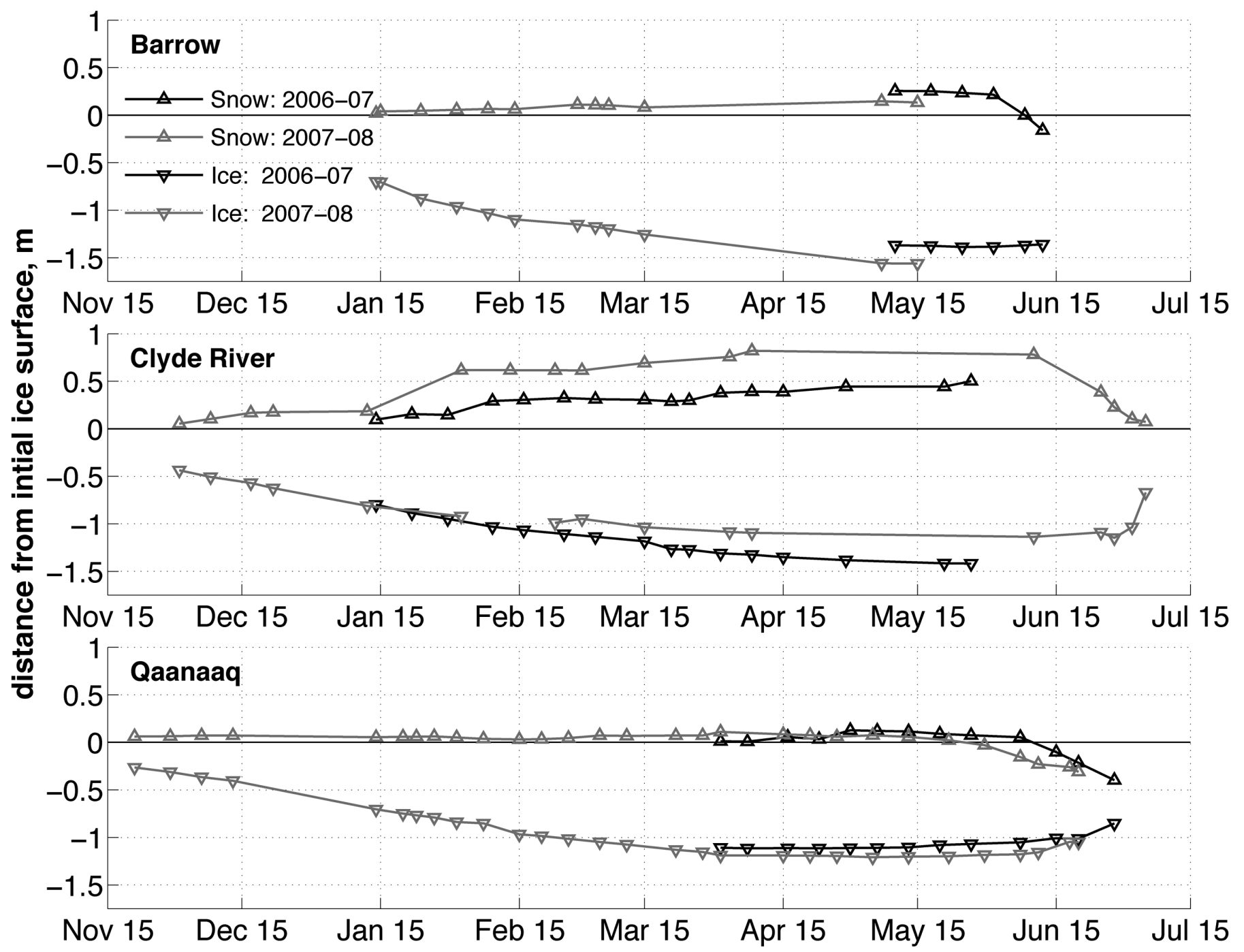

FIG. 4. Sea ice thickness and snow depth (in meters) for one measurement station at each community during the $2006-07$ and $2007-08$ sea-ice seasons. Negative snow depth indicates ice melt at the upper surface. The data, which were collected by members of the communities, capture the growth and melt of the ice, as well as variation between the communities and from year to year.

sea ice. The local researchers, who also set the agenda for discussions, selected group members for their level of expertise, compatibility with this type of collaboration, and willingness to take part. Later, communication among the different groups allowed the creation of some common agenda items and foci for discussions, but these were outgrowths of the initial, locally directed efforts. The site visits allowed community members to interact with one another, to compare their own areas with conditions at the other locations, and to engage more fully in the analysis of all the information gained about sea ice, how it is used, and how it is changing. The information gathered extended far beyond sea-ice thickness, the main parameter measured at the instrumental sites, though in an example of synergy between project components, the instrumental record provided a quantitative, objective basis for further discussion and comparison.

As in the Bidarki Project, friendships and shared interests played an important role in developing research relationships and project success. Both $\mathrm{H}$. Huntington and $\mathrm{S}$. Gearheard had been working in the communities of Barrow and Clyde River (respectively) for over a decade. H. Huntington lived in Barrow for several years, and S. Gearheard has been living full time for several years in Clyde River, where she has been learning and practicing traditional Inuit dogsledding. A. Mahoney took an intense interest in Inuit string games during the community exchange visits, to the amusement of the local teams.

\section{DISCUSSION}

Preparation and planning are vital to the success of a collaborative field effort, as they are for other kinds of research. While nothing can guarantee a successful exchange of information, researchers can help set up conditions that will foster mutually profitable exchanges. In addition to forming interpersonal relationships, discussed 


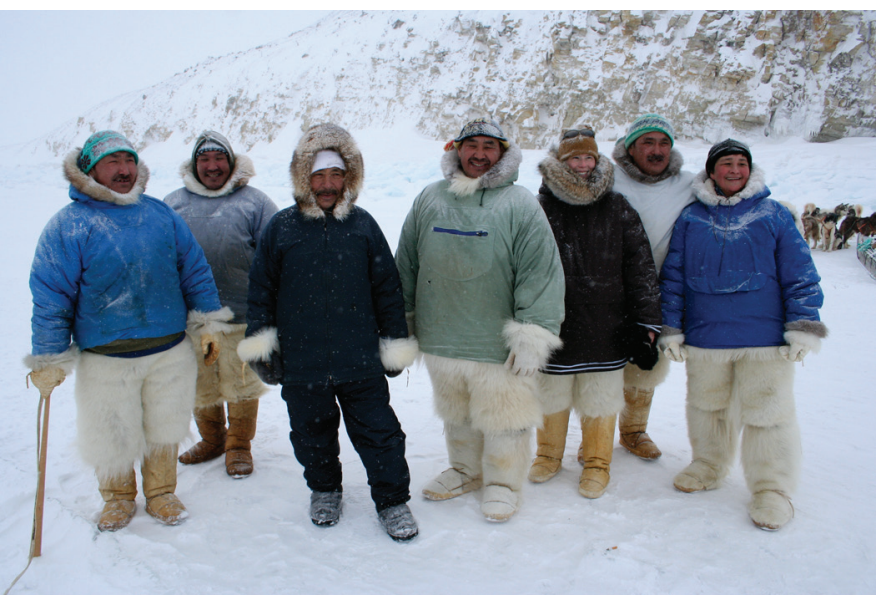

FIG. 5. Members of the Siku-Inuit-Hila team with residents of Qaanaaq, Greenland, during a journey with sled dogs. From left: Mikili Kristiansen, Illanguaq Qaerngaq, Ilkoo Angutikjuak, Rasmus Avilee, Shari Gearheard, Mamarut Kristiansen, and Lene Kielsen Holm. (Photo credit: Andy Mahoney.)

below, some logistical and practical steps can be taken. Those planning the field schedule should ideally arrange it to allow time for both formal and informal interactions and be mindful of the local seasonal round of activities, either to take advantage of local residents' being in the field or to avoid conflicts with local harvest schedules and other higher-priority activities for local residents.

Multiple visits to communities can be effective, if these are possible, but a field season that is not simply a rush to get things accomplished can also allow time for conversations and the pursuit of new lines of inquiry suggested by initial findings. Collaborative planning of the field effort can also help build a sense of shared contribution to the project, rather than placing one person in a permanently subordinate or passive role. Such a tangible demonstration that traditional knowledge is taken seriously can help encourage further sharing of ideas and insights. In the end, co-authorship, or at least a full acknowledgment of the role of local researchers and informants, may be appropriate (e.g., Huntington, 2006).

In both projects considered here, establishing strong relationships with local residents was an essential element of success. Those relationships fostered trust and created shared goals. Local residents understood the research and its significance, and the academic researchers understood what was important to the residents, both in relation to the project and in community life more generally. Communication became easier and more rewarding. This progression is similar to, and corroborates, that described by ParradoRosselli (2007).

Strong relationships, however, do not happen by accident, nor are they a guaranteed outcome. Several elements appear to contribute to success or failure in this regard. First, personalities are crucial. This is not to say that some personality types are ill-suited to collaborative research, but rather to emphasize that social skills should not be underestimated. Field research often involves physical discomfort and fatigue, stresses that can cause or exacerbate interpersonal tension. The ability to tolerate discomfort, to diffuse tension, and to recover from hurt feelings is important. Failure to do so can result in reduced cooperation, jeopardizing both the field effort and subsequent attempts to gather more information. While it is not possible to control for personalities entirely, attention to compatibility and to sustaining good working relationships is worthwhile.

Second, the right local partners are essential. A boat owner may be able to provide logistical support, but he or she may not be the ideal person with whom to discuss environmental conditions or findings. For projects in which traditional knowledge is ancillary, selection on the basis of logistical or other technical capacity may be appropriate. For projects in which traditional knowledge is central, experts or elders may be the optimal partners even if they are no longer active hunters or cannot provide logistical support in the field. Factors to consider include personal expertise, connection to others in the community who have expertise (i.e., the degree to which a participant can help open other doors), and of course personality and the capacity to take part in the field effort. In many communities and many projects, elders are regarded as the ultimate (if not sole) source of authoritative knowledge. However, many elders are no longer able to spend extended periods in the field, and engaging their knowledge requires other methods. Nonetheless, fieldwork by researchers can still establish a common basis of experience, even though separated in time.

Third, collaborative fieldwork may serve as an entry point and not only as an end in itself. Field conditions may not always be conducive to exchanging information or to recording such exchanges. Further discussions, including interviews, may be appropriate at times and locations when full attention can be devoted to the conversation. In both projects discussed here, the further interviews and discussions were essential to gathering extensive and detailed information, even when the initial topic had arisen from or during the fieldwork. Local residents can also provide highly valuable labor and expertise for carrying out ongoing measurement programs.

The success of Siku-Inuit-Hila's observation program was largely due to the diligent efforts of the (paid) local researchers who collected high-quality data. Autonomous measurement programs can be expensive and fickle. By comparison, engaging the local community in monitoring efforts is likely to be cheaper and can produce other benefits as well. In the case of Siku-Inuit-Hila, the communities came to take ownership of the monitoring program, independently launching and maintaining the stations during the sea-ice season once they gained experience. At Clyde River, residents decided to keep the program running, successfully applying for and obtaining additional funding from a federal program. In addition, communities in Nunavik, Quebec (Chris Furgal, pers. comm. 2009), have adopted the monitoring technology and methodology developed in Siku-Inuit-Hila, as has Parks Canada (Paul Ashley, pers. comm. 2009), which has launched new sea-ice 
monitoring programs based on that approach in several other Nunavut communities.

Where collaborative fieldwork is possible, its use in combination with other, more structured approaches to engaging traditional knowledge (such as interviews or group discussions) seems ideal. Consistent with the conclusions of Parrado-Rosselli (2007), we believe that greater emphasis on collaborative activity, and more widespread acknowledgment that a planned rather than opportunistic approach increases the likelihood of success, will spur better communication and result in growing scientific sophistication among local residents and improvements in research and its application by scientists.

\section{ACKNOWLEDGEMENTS}

We thank the communities who encouraged, supported, and assisted in our research: Port Graham, Nanwalek, and Barrow, Alaska; Clyde River, Nunavut, Canada; and Qaanaaq, Greenland. We also thank the Gulf Ecosystem Monitoring and Research Program (GEM project \# 030647), the National Oceanic and Atmospheric Association, and the National Science Foundation (Award No. 0624344) for funding our research. Finally, we thank colleagues, including Martha Dowsley, George Wenzel, and anonymous reviewers, who provided helpful feedback on the manuscript, and Karen McCullough for her characteristic editorial skill.

\section{REFERENCES}

Agrawal, A. 1995. Dismantling the divide between indigenous and scientific knowledge. Development and Change 26(3):413 -439.

Areki, F., and Fiu, M. 2005. Climate witness: Report for Kabara, Lau, Fiji Islands. Suva, Fiji: WWF South Pacific Programme. $73 \mathrm{p}$.

Berkes, F. 1999. Sacred ecology: Traditional ecological knowledge and resource management. Philadelphia, Pennsylvania: Taylor \& Francis.

Berkes, F., Berkes, M.K., and Fast, H. 2007. Collaborative integrated management in Canada's North: The role of local and traditional knowledge and community-based monitoring. Coastal Management 35(1):143-162.

Bernard, H.R. 1995. Research methods in anthropology: Qualitative and quantitative approaches, 2nd ed. Walnut Creek, California: AltaMira Press.

Briggs, C.L. 1986. Learning how to ask: A sociolinguistic appraisal of the role of the interview in social science research. Cambridge: Cambridge University Press.

Brook, R.K., Kutz, S.J., Veitch, A.M., Popko, R.A., Elkin, B.T., and Guthrie, G. 2009. Fostering community-based wildlife health monitoring and research in the Canadian North. EcoHealth 6:266-278.

Cruikshank, J. 2001. Glaciers and climate change: Perspectives from oral tradition. Arctic 54(4):377-393.
Dowsley, M., and Wenzel, G. 2008. "The time of the most polar bears": A co-management conflict in Nunavut. Arctic 61(2):177-189.

Ferguson, M.A.D., and Messier, F. 1997. Collection and analysis of traditional ecological knowledge about a population of Arctic tundra caribou. Arctic 50(1):17-28.

Ford, J., and Martinez, D. 2000. Traditional ecological knowledge, ecosystem science, and environmental management. Ecological Applications 10(5):1249-1340.

Fraser, D.J., Coon, T., Prince, M.R., Dion, R., and Bernatchez, L. 2006. Integrating traditional and evolutionary knowledge in biodiversity conservation: A population level case study. Ecology and Society 11(2): 4, http://www.ecologyandsociety. org/vol11/iss $2 /$ art4.

Gearheard, S., and Shirley, J. 2007. Challenges in communityresearch relationships: Learning from natural science in Nunavut. Arctic 60(1):62-74.

Gearheard, S., Matumeak, W., Angutikjuaq, I., Maslanik, J., Huntington, H.P., Leavitt, J., Matumeak Kagak, D., Tigullaraq, G., and Barry, R.G. 2006. "It's not that simple": A collaborative comparison of sea ice environments, their uses, observed changes, and adaptations in Barrow, Alaska, USA, and Clyde River, Nunavut, Canada. Ambio 35(4):204-212.

Huntington, H.P. 1998. Observations on the utility of the semidirective interview for documenting traditional ecological knowledge. Arctic 51(3):237-242.

- 2000. Using traditional ecological knowledge in science: Methods and applications. Ecological Applications 10(5):1270-1274.

2006. Who are the "authors" when traditional knowledge is documented? (Commentary) Arctic 59(3):iii-iv.

Huntington, H.P., and the Communities of Buckland, Elim, Koyuk, Point Lay, and Shaktoolik. 1999. Traditional knowledge of the ecology of beluga whales (Delphinapterus leucas) in the eastern Chukchi and northern Bering seas, Alaska. Arctic 52(1):49-61.

Huntington, H.P., Brown-Schwalenberg, P.K., Frost, K.J., Fernandez-Gimenez, M.E., Norton, D.W., and Rosenberg, D.H. 2002. Observations on the workshop as a means of improving communication between holders of traditional and scientific knowledge. Environmental Management 30(6):778-792.

Huntington, H.P., Suydam, R.S., and Rosenberg, D.H. 2004a. Traditional knowledge and satellite tracking as complementary approaches to ecological understanding. Environmental Conservation 31(3): $177-180$.

Huntington, H.P., Callaghan, T., Fox, S., and Krupnik, I. 2004b. Matching traditional and scientific observations to detect environmental change: A discussion on Arctic terrestrial ecosystems. In: The Royal Colloquium: Mountain Areas: A Global Resource. Ambio Special Report 13:18-23.

Huntington, H.P., Trainor, S.F., Natcher, D.C., Huntington, O.H., DeWilde, L., and Chapin, F.S., III. 2006. The significance of context in community-based research: Understanding discussions about wildfire in Huslia, Alaska. Ecology and Society 11(1): 40, http://www.ecologyandsociety.org/vol11/iss1 /art40/. 
Huntington, H.P., Gearheard, S., and Kielsen Holm, L. 2010. The power of multiple perspectives: Behind the scenes of the SikuInuit-Hila Project. In: Krupnik, I., Aporta, C., Gearheard, S., Laidler, G.J., and Kielsen Holm, L., eds. SIKU: knowing our ice. Dordrecht, Netherlands: Springer. 257-274.

Ingold, T., and Kurttila, T. 2000. Perceiving the environment in Finnish Lapland. Body and Society 6(3-4):183-196.

Johannes, R.E. 1981. Words of the lagoon: Fishing and marine lore in the Palau District of Micronesia. Berkeley: University of California Press.

Jorgensen, D.L. 1989. Participant observation: A methodology for human studies. Thousand Oaks, California: Sage Publications.

Mahoney, A., and Gearheard, S. 2008. Handbook for communitybased sea ice monitoring. NSIDC Special Report 14. Boulder, Colorado: National Snow and Ice Data Center. http://nsidc.org/ pubs/special/nsidc_special_report_14.pdf.

Mahoney, A., Gearheard, S., Oshima, T., and Qillaq, T. 2009. Sea ice thickness measurements from a community-based observing network. Bulletin of the American Meteorological Society 90:370-377.

Malinowski, B. 1922. Argonauts of the Western Pacific: An account of Native enterprise and adventure in the archipelagoes of Melanesian New Guinea. London: Routledge and Kegan Paul.

Markel, R.W., and DeWreede, R.E. 1998. Mechanisms underlying the effect of the chiton Katharina tunicata on the kelp Hedophyllum sessile: Size escapes and indirect effects. Marine Ecology Progress Series 166:151-161.

Murray, G., Neis, B., Palmer, C.T., and Schneider, D.C. 2008. Mapping cod: Fisheries science, fish harvesters' ecological knowledge and cod migrations in the northern Gulf of St. Lawrence. Human Ecology 36(4):581 - 598.
Nadasdy, P. 1999. The politics of TEK: Power and the "integration" of knowledge. Arctic Anthropology 36(1-2):1-18.

Naidoo, R., and Hill, K. 2006. Emergence of indigenous vegetation classifications through integration of traditional ecological knowledge and remote sensing analyses. Environmental Management 38(3):377-387.

Paine, R.T. 1992. Food-web analysis through field measurement of per capita interaction strength. Nature 355:73-75.

- 2002. Trophic control of production in a rocky intertidal community. Science 296:736-739.

Parrado-Rosselli, A. 2007. A collaborative research process studying fruit availability and seed dispersal within an indigenous community in the middle Caqueta River region, Colombian Amazon. Ecology and Society 12(2): 39, http:www. ecologyandsociety.org/vol12/iss2/art39/.

Parris, T.M. 1999. Connecting with citizen science. Environment 41(10):3.

Pierotti, R., and Wildcat, D. 2000. Traditional ecological knowledge: The third alternative (Commentary). Ecological Applications 10(5):1333-1340.

Salomon, A.K., Tanape, N.M., Sr., and Huntington, H.P. 2007. Serial depletion of marine invertebrates leads to the decline of a strongly interacting grazer. Ecological Applications 17(6):1752- 1770 .

Salomon, A., Huntington, H., and Tanape, N., Sr. 2011. Imam cimiucia: Our changing sea. Fairbanks, Alaska: Alaska Sea Grant.

Schnoor, J.L. 2007. Citizen science. Environmental Science \& Technology 41(17):5923.

Smucker, T.A., Campbell, D.J., Olson, J.M., and Wangui, E.E. 2007. Contemporary challenges of participatory field research for land use change analyses: Examples from Kenya. Field Methods 19(4):384-406, doi:10.1177/1525822X07302137. 